\title{
Integrating sense of place into ecosystem restoration: a novel approach to achieve synergistic social-ecological impact
}

\author{
$\underline{\text { Kelly M. Kibler }}^{1}, \underline{\text { Geoffrey S. Cook }}^{2}, \underline{\text { Lisa G. Chambers }}{ }^{2}$, Melinda Donnelly $^{3}$, Timothy L. Hawthorne ${ }^{4}$ Fernando I. Rivera $^{4}$ and Linda $^{2}$
} $\underline{\text { Walters }}^{2}$

\begin{abstract}
It is often a challenge to predict the impact of ecosystem restoration because many critical relationships and feedbacks between natural and human systems are poorly understood. To address this knowledge gap, we introduce a novel framework to characterize restoration dynamics within coupled human-natural systems. Because dynamics surrounding restoration are complex, we investigate the potential for sense of place, i.e., emotional attachment to place, to elucidate relationships between human and natural systems during times of change, such as restoration. Integrating sense of place with ecological metrics, a typology of restoration scenarios that exemplify complex relationships between social and ecological drivers emerges. We propose an identify-visualize-create framework for parsing restoration objectives and curating sense of place around the functional ecosystem state. Achieving coupled human-natural objectives thus requires evaluation of baseline sense of place early in the restoration process and active pursuit of opportunities that build stakeholder attachment over the long term.
\end{abstract}

Key Words: coupled human-natural systems; ecosystem services; identify-visualize-create; resilience; restoration success; stakeholders

\section{INTRODUCTION}

Human activities fundamentally alter natural systems (Lubchenco et al. 2015, UN 2015), threatening the sustained provisioning of ecosystem services (Costanza et al. 1997, Farber et al. 2006), and future resilience of coupled human-natural systems (Schroter et al. 2005, Cutter et al 2008, Mooney et al. 2009, Carpenter et al. 2012, Mumby et al. 2014, Cinner et al. 2015). Restoration, as an attempt to shift the current state of an ecosystem to a preferred state (Elliott et al. 2007), is one of few human activities designed to directly benefit ecosystems. Through restoration, humans are inextricably linked to the natural systems they seek to renew. The natural system ideally responds to restoration through enhanced functionality, ecosystem service production (Abelson et al. 2015), and resilience to perturbation. Despite the increasing prevalence and importance of restoration, there is a persistent and critical knowledge gap in understanding what constitutes success (Kondolf and Micheli 1995, Ruiz-Jaen and Aide 2005) and whether or not accepted metrics of success, e.g., area restored, survival rate of plantings, or number of volunteers involved indeed indicate measurable impact, e.g., improvements to ecological function or enhanced stakeholder attachment (Stanturf et al. 2001, Bernhardt et al. 2007).

Historically, the impact of restoration to natural and human systems has been assessed by modeling the two systems as separate entities (e.g., Molles et al. 1998, Ogden et al. 2005, Cooper et al. 2007, Elliott et al. 2007). However, more inclusive frameworks to consider human and natural system components in concert have been proposed (e.g., Geist and Galatowitsch 1999, Clewell and Aronson 2006, Spies et al. 2014). The coupled human-natural system (also termed social-ecological system) is complex; feedbacks between the human and natural system are often abstract, indirect, and nonlinear. To measure and express these relationships quantitatively is challenging. However, failing to understand these critical pathways through which restoration impacts society may result in missed opportunities to synergize stakeholder engagement in the restoration process. For instance, human perceptions are reported as important dimensions for success of river and coral reef restoration (Åberg and Tapsell 2013, Westling et al. 2014, Kittinger et al. 2016). Several authors demonstrate that stronger sense of place often leads to individual or group action (Bonaiuto et al. 2002, Devine-Wright 2009, Scannel and Gifford 2010, Masterson et al. 2017). By leveraging individual perceptions or feelings that translate into behavioral changes, or collective actions that generate adaptive capacity (sensu Adger 2006), the ecosystem impacts of restoration may be magnified or become more sustainable.

Coupling information conveying sense of place with ecological metrics may elucidate complex relationships between the social and ecological drivers of restoration. The term sense of place, first introduced by Tuan (1977), refers to the meaning an individual or group ascribes to a geographic location. The terms "sense of place" and "attachment to place" are often used interchangeably. From a social science perspective, sense of place most often considers three related characteristics: a physical location, activities in that location, and meanings and attachments connected to human experiences and psychological connections to the physical location (Stedman 2003). Put another way, a physical setting (geographic space) gains its meanings (becomes a place) through one's experiences with and in it (Relph 1976, Shamai 1991, Massey 1993, Jorgensen and Stedman 2001). Sense of place may be an appropriate framework to distinguish how restoration ignites emotion within human communities, and can identify opportunities to leverage emotional attachment into actions that improve ecosystem function. Furthermore, such information may be useful in predicting whether improved ecological conditions are likely to persist, or if restored systems are likely to revert back to a state of degradation due to an inability to address the drivers of degradation.

${ }^{1}$ Department of Civil, Environmental \& Construction Engineering and National Center for Integrated Coastal Research, University of Central Florida, ${ }^{2}$ Department of Biology and National Center for Integrated Coastal Research, University of Central Florida, ${ }^{3}$ Department of Biology, University of Central Florida, ${ }^{4}$ Department of Sociology, University of Central Florida 
We propose a construct of restoration dynamics within coupled human-natural systems and define and operationalize the complex and highly interactive relationships between human and natural subsystems. Highlighting the potential role of sense of place in understanding relationships between human and natural systems, we propose a new framework of concrete actions to embed coupled human-natural objectives within the restoration process. The proposed identify-visualize-create (IVC) framework is structured to apply broadly to diverse restoration situations and to encompass heterogeneous ecosystems, restoration objectives, and human stakeholders. After examining the role of restoration and sense of place within human-natural systems, we introduce the individual components of the IVC framework and provide case study examples of how differing strengths of ecological function and sense of place can produce unique restoration outcomes.

\section{RESTORATION WITHIN THE HUMAN-NATURAL SYSTEMS FRAMEWORK}

Human-natural systems are complex organizations of interconnected subsystems and state variables spanning multiple ecosystem levels, which by definition include human society (Walker et al. 2004, Liu et al. 2007). At the most basic organization, a human-natural system consists of the resource system under consideration, resource units composing that system, and resource users (Ostrom 2009). Reciprocal feedbacks between subsystems drive the capacity of the system to respond to perturbation in manners either beneficial or nonbeneficial to the ecosystem state. Vulnerability and resilience frameworks developed in parallel within the social and natural sciences (Luers et al. 2003, Gallopin 2006) present a means of expressing system response and capacity. Vulnerability captures the idea of susceptibility to harm, including sensitivity and exposure to perturbation (Adger 2006), while resilience describes the capacity of a system to maintain a stable state in the face of perturbation (Eakin and Luers 2006, Folke 2006). In coupled human-natural systems, these two frameworks are closely entwined, and at their confluence is the concept of adaptive capacity (Turner et al. 2003, Cutter et al. 2008, Engle 2011). Adaptive capacity influences vulnerability by mitigating sensitivity to perturbation, while within a resilience framework, adaptive capacity relates to the capacity of a system to absorb stress, and the ability of actors to modulate transitions among desirable coupled natural-human states (Walker et al. 2004, Adger 2006, Robards et al. 2011). There is a growing recognition that actors within complex systems can impact system resilience (Carpenter and Brock 2008, Folke et al. 2010, Engle 2011).

When ecosystem restoration is framed within the context of human-natural systems (Fig. 1), there are a multitude of positive and negative interactions among components comprising the human and natural subsystems, and these reciprocal feedbacks drive the ensuing dynamics of the coupled system (Fig. 2). As depicted in Figure 2, unsustainable human resource use, e.g., overfishing, or alteration of natural processes, e.g., hydrologic alteration, shoreline armoring, or nutrient loading, may lead to ecosystem degradation (1) and loss of ecosystem services (2). Such degradation increases vulnerability in natural and human systems by lowering the capacity to adapt to and absorb stresses (3). Uniquely, restoration is a human activity that provides a service to the natural system (4), with potential to profoundly transform human and natural systems. When key natural processes and functions are restored, ecosystem services may recover (5), leading to enhanced human well-being, e.g., health and livelihood security (Millennium Ecosystem Assessment 2005) (6), and resilience within the coupled human and natural systems (7).

Fig. 1. General conceptual model of a coupled human-natural system (sensu Ostrom 2009), incorporating the role of ecosystem restoration.

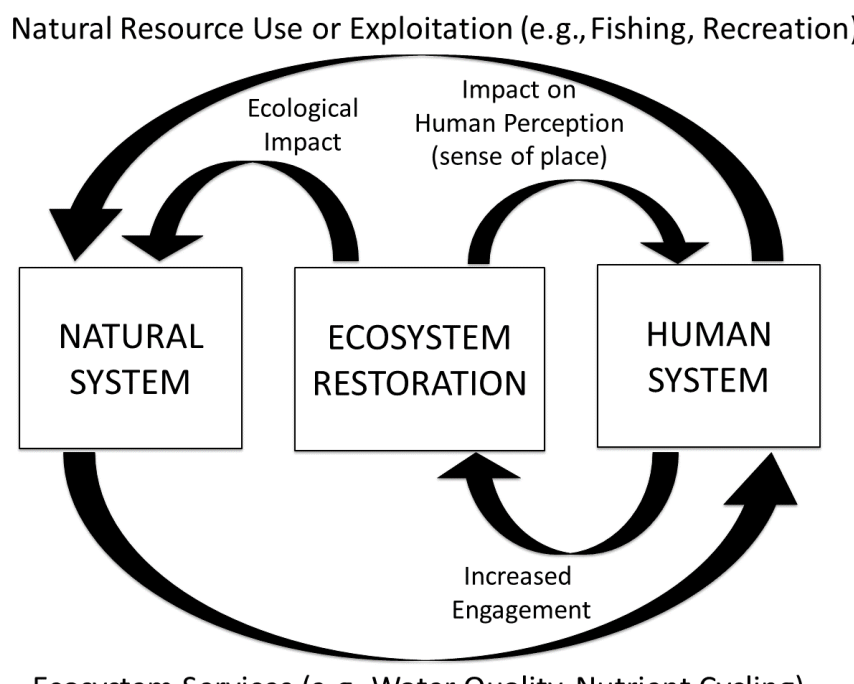

Ecosystem Services (e.g., Water Quality, Nutrient Cycling)

Beyond the socioeconomic implications of ecosystem services recovery, restoration acts upon the human system by altering human perceptions of the natural system and its value (8-13). Direct participation or indirect support of restoration binds people to the places they work to restore, creating sense of place (8). The impact of sense of place generated by restoration, to both human and natural systems, particularly with respect to its role in changing emotional attachment (9) and subsequent behavior toward the natural system (10), is poorly understood. Perceptions are important because they can shape reality (Rivera and Kapucu 2015). Thus, if it is perceived that a natural system, such as a coastal area, is an attractive place to entertain and live, this may lead to increased development, resource exploitation, and potential ecosystem degradation (11, nonbeneficial feedback). Alternatively, restoration success (or simply perception of success) may inspire further human interest and value attributed to services provided by the intact ecosystem. In this way, initial restoration success (or perception of success) may be a driver of further impact through subsequent restoration, public awareness and activism, behavioral changes, and political pressure to restore and protect ecosystems. Through these mechanisms, we posit that positive human perceptions created through restoration can cascade into beneficial feedbacks (12-13), including subsequent restoration activities (13).

As restoration science has evolved, there have been considerable advances in methods to restore natural systems and monitor ecosystem response. Simultaneously, metrics and methods have been proposed to assess the human dimensions of restoration success vis-a-vis anthropogenic goals of improving social equity, 
Fig. 2. Feedbacks between human and natural systems, with restoration as a focal point. Solid boxes are actions, dashed boxes outcomes, and thick solid boxes outline the social and ecological components of general conceptual model from Figure 1.

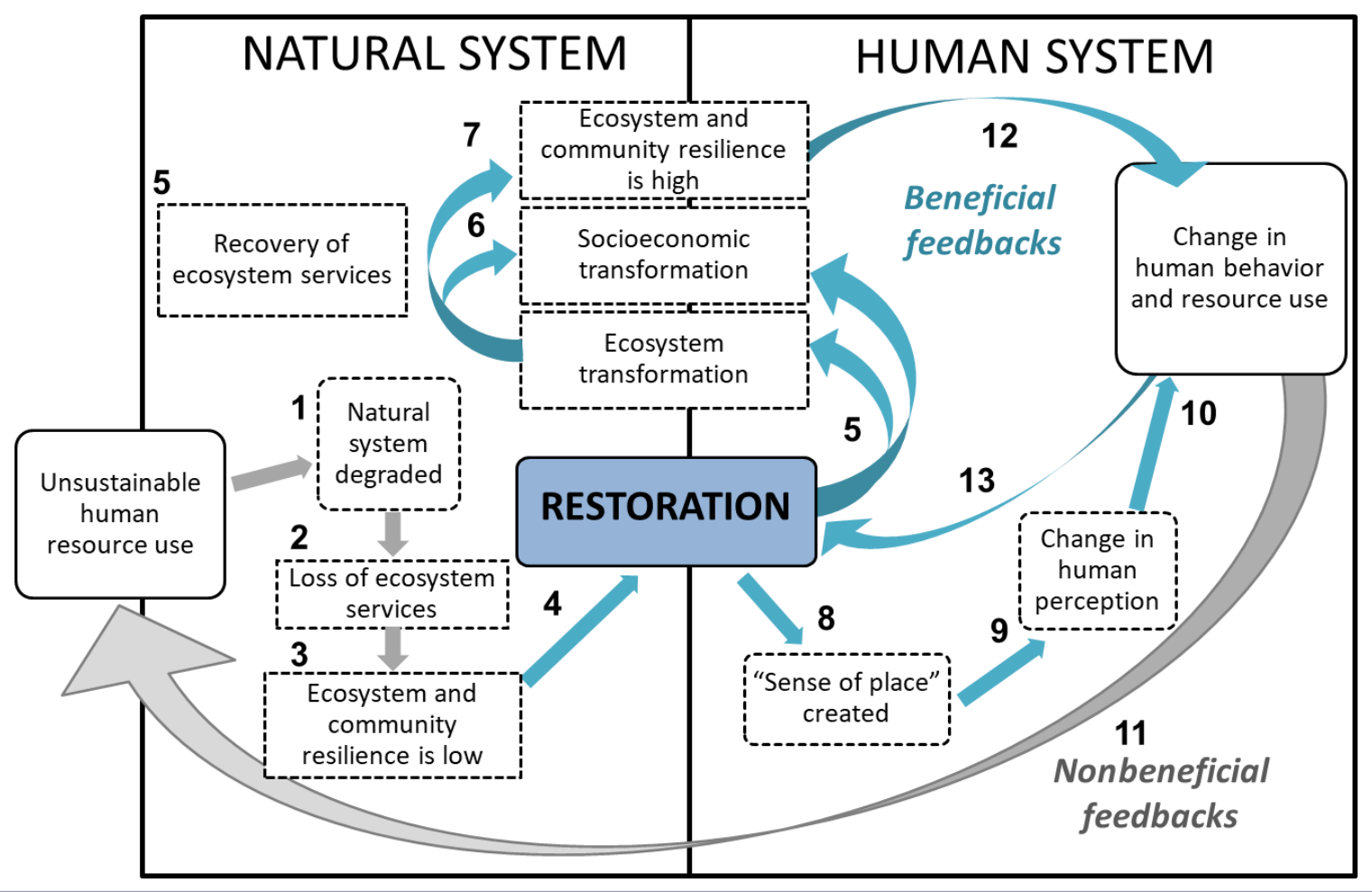

economic sustainability, and human well-being (Aronson and Alexander 2013, Palmer and Ruhl 2015). For instance, number of volunteers involved in restoration activities, economic return on restoration, hedonic value, and human perceptions of success are proposed to monitor human-dimensional goals (Higgs 2012, France 2016, Marttila et al. 2016). However, in restoration implementation or research, social and ecological fields often proceed along parallel, yet unconnected paths, resulting in a relative paucity in approaches to quantify success of restoration at the coupled human-natural level (Wortley et al. 2013). To that end, the influence of success on the human level to overall ecosystem impact is poorly characterized, and potentially undervalued. For example, if a restoration project fails to significantly improve ecosystem function, but inspires participants and surrounding community members to continue working toward positive environmental changes, can it be said the restoration was wholly unsuccessful? Community engagement within the restoration process may have potential to harness the power of sense of place, creating a feedback of positive impact (e.g. Fig. 2, 12-13). Participation and engagement may serve as a foundation for new connections between individuals or groups of actors and the natural system, leading to subsequent engagement in activities aimed at improving ecological conditions. Such engagement could potentially extend to altered behaviors. For instance, a homeowner may choose to alter fertilizer applications to their lawn after helping to restore a degraded waterbody. Alternatively, the created sense of place could manifest as enhanced participation in further restoration, financial contributions to local environmental groups, or political action.

\section{INTEGRATING HUMAN DIMENSIONS INTO ECOSYSTEM RESTORATION: THE IDENTIFY- VISUALIZE-CREATE FRAMEWORK}

Given the challenges inherent to restoring complex and stochastic natural systems, achieving successful and impactful ecosystem restoration requires long-term commitment from engaged stakeholders (Palmer et al. 2005, Reed 2008, Lee and Hancock 2011). Building and sustaining coalitions of support must therefore be prominently featured within program objectives (Aronson and Alexander 2013). Yet despite this critical importance, frameworks to integrate human dimensions within ecosystem restoration are lacking, and many restoration efforts do not include project objectives specific to the human system. Restoration practitioners may wish to understand and leverage stakeholders' sense of place to maximize the impact of restoration, yet struggle to know how to do so. With these points in mind, we propose a sequence of identify-visualize-create (IVC) as a novel framework to integrate human dimensions into ecosystem restoration. In-depth explanation and example applications of the IVC framework follow and are centered on three general steps. Prior to ecosystem restoration, practitioners (1) identify baseline stakeholder sense of place regarding the ecosystem considered for restoration. Subsequently, sense of place is coupled with biophysical data to (2) visualize the current position of the ecosystem along the sense of place-ecosystem function plane (Fig. 3), and assess the predicted trajectory and related probability of restoration success nested within the given human-natural system under consideration (Fig. 4). Finally, practitioners use this knowledge to strategically (3) create 
opportunities for building human attachment to the functional ecosystem state, harnessing the power of sense of place to achieve greater long-term efficacy of ecosystem restoration within complex human-natural systems.

Fig. 3. Likelihood of ecosystem improvement with restoration in coupled human-natural space.

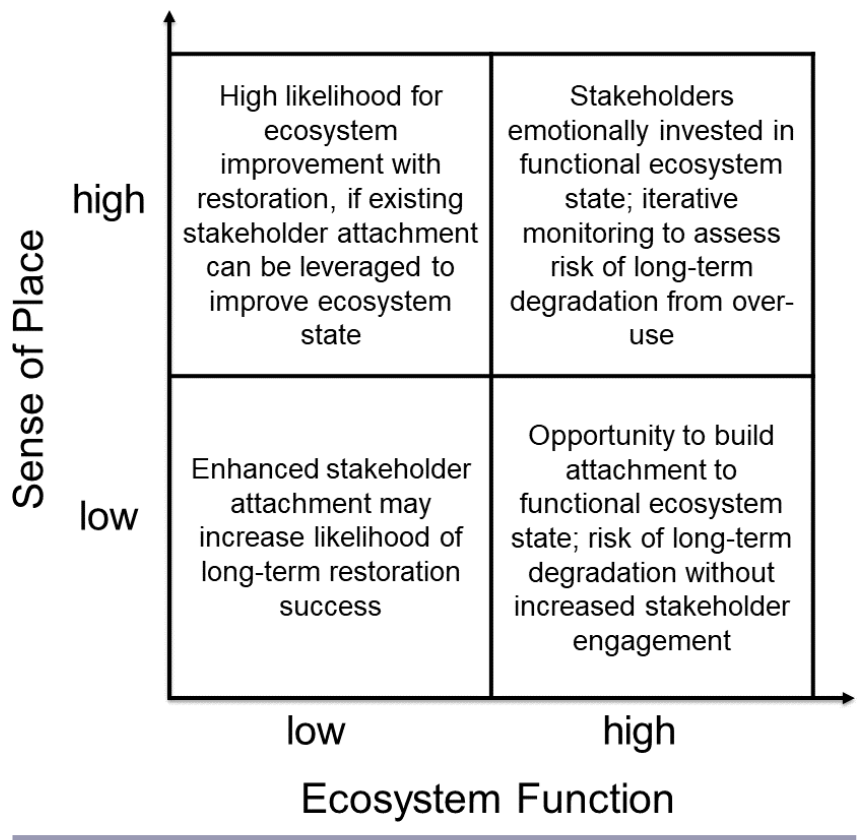

Fig. 4. Potential trajectories of ecosystem degradation and restoration in coupled human-natural space.

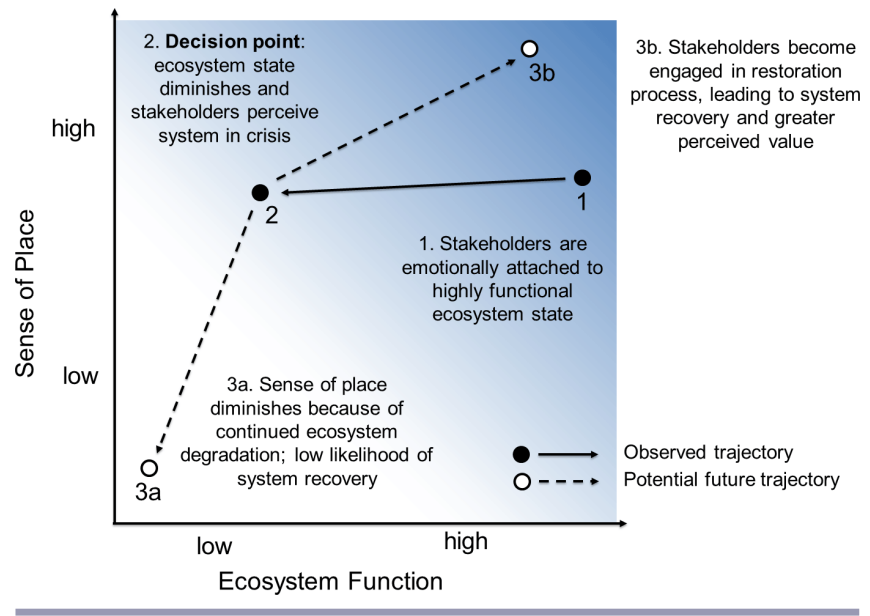

\section{Identify existing human attachment to ecosystem state}

By its very nature, restoration entails change to a physical/ biological landscape, or to the range of activities and benefits that may be realized from a particular space. The prerestoration state may have persisted for generations and may be the only state that local stakeholders have known. Attachment to the known, and fear of the unknown, may present emotional challenges at the outset of proposed restoration (Elston 2009). Although the prerestoration state is perhaps not ideal with respect to some factors, i.e., environmental and ecological attributes, safety, or risk, humans may resist environmental change because of the attachment they have developed to the place over time (Bohlen et al. 2009). For example, river restoration within the context of the Room-for-the-River scheme in the Netherlands transformed generations-old agricultural landscapes into working floodplains for flood mitigation and ecosystem restoration, causing distress among some stakeholder groups despite the multiple benefits created for other people and species (Buijs 2009, Edelenbos et al. 2017). At the outset of restoration, and especially during critical times of decision making and building community buy-in for a project, the power of such emotional hurdles cannot be underestimated. In another example, the community of Hope Mills, North Carolina, ultimately decided to rebuild a defunct mill dam following its failure despite the lower cost and clear safety and ecological benefits to be realized by the undammed river (Kibler, unpublished data). Local stakeholders were unable to abide the loss of the reservoir in a central location of town, which many felt was an encapsulation of the town's history as a mill town. The Hope Mills dam rebuilding exemplifies how ecologically justified actions may be called into question in the face of strong emotional attachment.

Identifying existing sense of place as a first step in the IVC framework may illuminate ways in which individuals and groups experience place and how such meaning might impact their views on restoration in the short and long term. Similar to the ecosystem services concepts of cultural services (Small et al. 2017) and cultural ecosystem services (Satz et al. 2013), sense of place is an arguably vague concept (Relph 1976, Shamai 1991) that can be difficult to measure objectively (Shamai and Ilatov 2005). It is highly variable based on individual and group perceptions (Massey 1993) and has potential to change dynamically through time, even within a single group. As such, sense of place may be best presented as a process rather than a state, that is influenced by the multiple ways in which individuals differentially experience place, i.e., experience sensory and emotional perceptions connected to a particular geographic location, based on socially constructed identities (Valentine 2007). Typically represented as qualitative data, sense of place is neither objective nor generalizable across geographic locations. Furthermore, how individuals develop and/or share sense of place is complicated by an individual's identity related to the social constructions of class, gender, and race (Rose 1995). For example, a wealthy developer might experience an affluent coastal community differently (and thus have a different sense of place) than a lower-income person. In order to measure sense of place, social scientists often use qualitative methods such as focus groups or in-depth interviews to understand the meanings individuals or groups ascribe to a physical location. A more innovative approach to measuring sense of place involves participatory sketch mapping (Boschmann and Cubbon 2014). Data collection through sketch mapping involves participants marking a paper or digital map where they feel high or low attachment to a location. For example, an individual might be asked to draw on a map all areas where they feel a strong emotional attachment to a community. The individual would then be asked to explain his or her drawings on the map through a series of follow-up interview questions. 
Throughout the process of restoration, both the substantive (what is done) and procedural (how it is done) are likely to influence the overall impact at the coupled human-natural level. In addition to seeking high ecosystem impact through the substantive restoration, identifying the emotional components of a restoration project at the outset and designing processes to build attachment to functional ecosystems will enhance long-term sustainability (Fig. 2, 8-10). Understanding and acknowledging stakeholders' baseline sense of place in the planning process can afford restoration practitioners an opportunity to address concerns and potentially mobilize existing stakeholder attachment toward an improved ecosystem state. For instance, educational programs may build value for the ecosystem functions targeted by restoration. Engagement in decision processes may facilitate community buy-in and allow issues of concern to be addressed early. Stakeholder concerns, such as loss of access, can be voiced and incorporated in planning. Giving communities a voice within the restoration process and acknowledging the legitimacy of attachments to a degraded system state may avoid alienation of key stakeholders. It is important to acknowledge that the IVC framework recognizes the potential for existence of several communities within a place. The perceptions of a multitude of stakeholders that represent the heterogeneity of views within the community must be understood before consensus can be reached on how to best proceed with restoration.

\section{Visualize systems in coupled human-natural space}

To facilitate the development of reciprocal beneficial feedbacks between human and ecological systems in restoration, a priori understanding of the likelihood for dual human-natural impact may be instructive to restoration planning. Such understanding may be enhanced by visualizing systems within a coupled humannatural space (Fig. 3), where sense of place and ecosystem state occur along continuums from low to high. To illustrate the potential utility of this step in the IVC framework, we describe restoration case studies that exemplify end-member states of coupled sense of place and ecosystem function space, and strategies for success within each quadrant of this typology.

\section{High sense of place, high ecosystem function}

Systems plotting in the upper quadrants of Fig. 3 are characterized by high sense of place, meaning that there is extant human attachment to the system. Systems in which ecosystem function is also high represent perhaps an ideal end state for management, as stakeholders have a well-developed sense of place that is tied to a highly functional ecosystem state. The combination of high sense of place and high ecosystem function would be expected to promote beneficial feedbacks within the coupled human-natural system (Fig. 2, 12-13). Systems in this quadrant are not currently in need of restoration; however, should the ecosystem degrade in the future from nonbeneficial feedbacks (Fig. 2,11), the high sense of place suggests a strong stock of human engagement and motivation to restore the ecosystem to its high functioning state (Fig. 2, 5-7).

High sense of place, low ecosystem function

Systems where strong sense of place has developed around a degraded ecosystem state may represent a challenging situation for restoration. For example, the Savage Rapids Dam, constructed on Oregon's Rouge River in 1921, no longer fulfilled its intended water supply purpose (Fig. 2, 1-2), but the reservoir was an enjoyable water feature for residential backyards and golf courses, and a popular destination for swimming and waterskiing (Robinson 2009). Though empirical evidence documented low ecological functioning of the Rouge River because of the dam (ODFW 2007), many stakeholders' sense of place had a strong foundation in appreciation for the degraded state, i.e., enjoyment of the recreational and aesthetic benefits of the artificial reservoir, promoting nonbeneficial feedbacks within the coupled humannatural system as related to ecosystem function (Fig. 2, 11). Approximately two decades of discussion ensued among numerous highly engaged stakeholder groups, each with their own vision of the optimal state of the Rouge River. Those whose sense of place was rooted in high ecological functioning for salmonid species eventually prevailed and the dam was removed in 2009 with the financial backing of Congress. From an ecological and geomorphic perspective, the restoration has been highly impactful (Tullos et al. 2014).

The Savage Rapids case study typifies dynamics around potential restoration projects where stakeholders value different preferred ecological states. An alternative example with similarities in stakeholder discourse, but thus far a different outcome, is the proposed removal of the Kirkpatrick Dam from the Ocklawaha River in Florida. Like the Savage Rapids Dam, the Kirkpatrick Dam does not fulfill its design purpose (Noll and Tegeder 2009), but is valued for the alternative ecological state created by the reservoir, a favorite angling spot. Despite convincing evidence of the negligible economic value of the reservoir (FDEP 1995), and research indicting the dam may diminish fish community health (Rogers et al. 2005, Lewis 2012), many local stakeholders vehemently oppose removal, and have thus far successfully prevented restoration efforts. These cogent examples illustrate the role of human emotion in restoration, and highlight the complex decision-making process that can ensue in the face of strong emotional attachments. Working within the IVC framework, if existing sense of place can be maintained and bolstered around restoring to a high-functioning ecological state (Fig. 1, 8-10), locations plotting into the low ecological function-high sense of place quadrant have great potential for restoration success and impact.

\section{Low sense of place, high ecosystem function}

Absence of strong attachment may also create challenges for ecosystem restoration. Because of lack of accessibility by permanent human populations, remote coral reefs are an example ecosystem that is often characterized by high ecosystem function, but may lack strong attachment from human advocates. Remote reefs serve as hotspots for biodiversity and productivity, but are often located on islands with low numbers of permanent residents, potentially limited resources to devote to conservation, e.g., Palmyra Atoll or Kingman Reef in the Northern Line Islands, or strong economic incentives to develop tourism industries. For example, many reefs near Roatan, Honduras are degrading because in part of increased visitor traffic and associated nonbeneficial feedbacks (Fig. 2, 11). After cruise ship docks opened in 2008 and 2010, tourist numbers grew exponentially, with 1.2 million visitors reported in 2011 (Doiron and Weissenberger 2014). Reefs, especially in waters near the cruise ship docks, suffered tourist overuse, which simultaneously reduced ecosystem function, enjoyment for locals and visitors, and decreased resilience of both the natural and human 
communities reliant on healthy coral reefs (Fig. 2, 1-3). Efforts in these types of systems require a focus on building attachment to the functional ecosystem (Fig. 2, 8-10), both in local and visitor communities, to be drawn upon to prevent system degradation and support restoration and conservation (Fig. 2, 12-13).

\section{Low sense of place, low ecosystem function}

Ecosystems characterized by both low ecosystem function and low sense of place may be exceptionally difficult to restore due to a lack of both perceived ecological worth and emotional attachment. Highly degraded systems located outside the public domain, such as reclaimed surface coal mines in the Appalachian deciduous forests in the eastern United States, may fall into the lower left quadrant of Fig. 3. Because mining activities typically occur in unpopulated and unvisited areas that are often privately owned, degradation, loss of ecosystem services, and decreased resiliency (Fig. 2, 1-3) can be perceived by the community as the responsibility of mining companies, with expectations that restoration and recovery will be supported by federal and state regulations for bonded reclamation (Holl and Howarth 2000, Holl 2002, Dallaire et al. 2015). In such systems that exemplify low ecosystem function and low sense of place, if restoration is to be pursued, it must often rely on state and federal mandates and financing because local communities may lack sufficient capacity or motivation. Furthermore, some degree of ecosystem recovery may be a necessary first step in attracting public interest and engagement to build sense of place before community-based restoration is possible (Fig. 2, 8-10). For example, recent efforts to promote reclamation practices to restore forests in the eastern U.S. has been led by the Appalachian Regional Reforestation Initiative (Jones et al. 2005, Angel et al. 2006), a coalition of federal, state, and local agencies, industry, environmental organizations, scientists, and private landowners.

\section{Create opportunities for building sense of place}

As discussed above, restoration can be a mechanism for building sense of place to restored places (Fig. 2, 8-13). For example, human attachment can be created within restoration volunteers during engagement in the restoration activity itself, if volunteers track site success either in person or social media, or if the site becomes a favorite recreational spot for volunteers because of their involvement with restoration efforts. However, sense of place creation may not be implicit within every restoration project; in many cases, opportunities for sense of place development must actively be sought. A key determining factor as to sense of place potential may lie in the extent and manner to which projects include broader community participation, both in the implementation and monitoring of restoration itself, and in the decision-making processes that lead to restoration. For example, restoration driven by grassroots efforts of community members will necessarily entail a high level of interaction among variable human actors. These efforts may be as diverse as fundraising, community organizing at local events, participation in public meetings, or direct participation in restoration activities, such as plantings, trash pick-ups, invasive species control, or monitoring by citizen scientists. In these cases, creation of sense of place among local stakeholders is fully implicit within the restoration process. By contrast, large-scale restorations planned, funded, and implemented within higher levels of governance may have fewer implicit inroads for creating sense of place. For example, restoration of flows to the lower Colorado River have been high- impact with respect to ecological metrics (Kendy et al. 2017, Nelson et al. 2017), and required complex interstate coordination between national water and environmental management agencies, dam managers, NGOs, and scientists. However, because direct integration of community participation is often not implicit in such large, agency-driven restoration projects, supplemental activities were necessary to connect community stakeholders to the restoration process.

Historically, most restoration effort is dedicated to maximizing impact with respect to the ecological system, which is often reflected in substantive project objectives containing physical or biological targets. Facilitating human emotional attachment to restored places must be similarly included as stand-alone objectives within the project, or activities to achieve human impact may be overlooked, potentially undermining long-term project success. For example, failed efforts to restore wetlands artificially impounded for mosquito control in Florida's Mosquito Lagoon perhaps suffered from a combination of local attachment to the altered ecosystem state, fear of losing access to restored areas, and inadequate attention to building sense of place around the restored ecosystem state. Restoration largely occurred on public land and project objectives included hydrologic and biological targets, coordinated by a multiagency collaboration of scientists, national and local government, and land managers. Despite its high-value ecosystem improvements (Rey et al. 2012), the project suffered poor public perception, eventually culminating in legal action by local citizen groups opposed to restoration. Although some level of friction between user groups may be inevitable during times of change, opportunities to avoid and minimize conflict may be found by identifying existing human emotional attachment to a place, visualizing potential system trajectories in natural-human space, and working to create attachment to a shared vision of the restored space. Finally, to adopt a tested strategy from ecological management, coupled human-natural objectives must be monitored through time and adjusted as required in an iterative, adaptive fashion.

\section{Understanding complex, dynamic systems through coupled human-natural trajectories}

The IVC framework offers restoration practitioners a prescribed methodology for integrating human attachment to place into restoration planning, and emphasizes system understanding on a dual plane of coupled human and natural system attributes. As emphasized by our conceptual model (Fig. 2), restoration within coupled human-natural systems is complex. Although there is value to visualizing complex systems though parsimonious and simplified frameworks, such as Fig. 3 , it is also necessary to consider the vast heterogeneity that must be encapsulated when visualizing the human-natural space. The complexities of ecosystem function and multiple, diverse stakeholder feelings are necessarily greatly simplified to better observe their confluence. It is emphasized that such simplification is not recommended when identifying and creating sense of place. These steps should specifically encompass the breadth of stakeholder voices, much in the way comprehensive ecological study may have been used to design the ecosystem restoration. When such baseline data are available, examining historic and hypothetical future system dynamics through the lens of coupled human-natural space may allow planners and communities to articulate shared visions of success, and provide further insights to where restoration efforts may be effectively focused. 
Case study: Indian River Lagoon estuary, Florida

Potential human-natural trajectories mapped through time in Florida's Indian River Lagoon (IRL; Fig. 4) highlight strong sense of place as a potential asset to ecosystem recovery. A large estuary located along Florida's Atlantic coast, and the most biologically diverse estuary in the Northern Hemisphere, the IRL ecosystem attracts many tourists, and has historically been a valued centerpiece of a devoted local community (Donnelly et al. 2017, Walters et al 2017). Human attachment to a functional ecosystem, representing combined economic, cultural, and emotional ties developed by the coastal community, has traditionally been strong. Over several decades, ecosystem function in the lagoon degraded (IRL NEP 2008). Loss of oyster reefs, seagrasses, and coastal wetlands, widespread shoreline erosion, harmful algal blooms, and fish kills contribute to a narrative of a system in crisis (Fig. 4, trajectory from 1 to 2). The system has reached a critical decision point, where two potential future trajectories are possible. On one hand, continued degradation of ecosystem function may lead to decline in sense of place (trajectory 4a), as the perceived value of the IRL to community stakeholders may diminish with the loss of ecosystem services. However, another narrative may be possible, in that the existing high value (historically high sense of place) may drive stakeholder action toward system recovery (trajectory 4b). Visualizing system trajectories in human-natural space suggests that the historically high sense of place may contribute to likelihood of restoration success (trajectory 4b), as community stakeholders are likely to support and be actively involved in restoration efforts. Indeed, community responses to ecosystem decline in IRL support this possibility. As ecosystem function degraded, losses of ecosystem function were experienced viscerally, and the community acted decisively to support restoration, involving many levels of governance and civil society. Countless volunteer hours have been donated by community members, coordination between local governments and regulatory bodies has expanded significantly, and local investments have been made in estuary science at all educational levels. Significantly, one coastal county voted with an overwhelming referendum to voluntarily raise sales taxes to robustly fund restoration within the IRL. Although biophysical impacts of the ongoing restoration largely remain to be seen, the strong attachment of community members and broad alignment of stakeholder preferences to a state of high ecological function suggest that long-term restoration success is attainable. Furthermore, the proposed coupled human-natural model suggests that the stakeholder-driven restoration effort may in itself be a mechanism to elevate sense of place and value for ecosystem state through beneficial human-natural feedbacks. The act of community members working to restore and recover ecosystem function may elevate stakeholder value, such that sense of place may be greater after restoration (Fig. 4, point $4 \mathrm{~b}$ ) than before ecosystem degradation (Fig. 4, point 1). For example, after participating in a restoration event, community volunteers in IRL are known to return to restoration sites regularly to check on progress (plant growth, etc.), track site success via social media, or return with fellow restoration volunteers for picnics or celebrations. Restored places become new favorite fishing or snorkeling spots, because in part of associated memories of time spent "saving the lagoon" with friends or loved ones.

\section{CONCLUSIONS}

As restoration becomes a widespread human response to ecosystem degradation, it is necessary to elevate definitions of restoration success to include impact at the level of coupled human-natural systems. Herein we have characterized restoration dynamics within coupled human-natural systems, finding that ecosystem restoration is governed by a network of reciprocal feedbacks between social and ecological systems. Coupled human-natural systems are complex, heterogeneous, and dynamic. Impactful restoration must satisfy a diverse portfolio of objectives, stakeholder preferences, and ecosystem dynamics. Notably, the impact of human system complexities to restoration success may be underappreciated. We posit that human perception and value of a place can be a potential driver of individual and community action, which may be characterized by sense of place. Although each ecosystem, human system, and restoration may be unique, all stand to benefit from better understanding and integration of human sense of place within management objectives. To incorporate integrated humannatural objectives within restoration planning, we propose an identify-visualize-create framework with the following actionable steps:

1. Identify and leverage or address existing stakeholder attachments to the ecosystem;

2. Visualize dynamic systems within human-natural space to support a priori understanding of restoration impact potential, and as a tool for creating a shared vision of the preferred future social-ecosystem state;

3. Create opportunities for sense of place realization throughout the restoration by articulating specific project objectives related to building stakeholder attachment.

When combined with a restoration plan rooted in strong ecosystem science, harnessing the power of stakeholder sense of place through the IVC framework may allow practitioners to achieve sustained success of ecosystem restoration within complex human-natural systems.

Responses to this article can be read online at: http://www.ecologyandsociety.org/issues/responses. php/10542

\section{Acknowledgments:}

Funding for this work is provided by the U.S. National Science Foundation (Award \#1617374).

\section{LITERATURE CITED}

Abelson, A., B. S. Halpern, D. C. Reed, R. J. Orth, G. A. Kendrick, M. W. Beck, J. Belmaker, G. Krause, G. J. Edgar, L. Airoldi et al. 2015. Upgrading marine ecosystem restoration using ecologicalsocial concepts. Bioscience 66:156-163. http://dx.doi.org/10.1093/ biosci/biv171

Åberg, E. U., and S. Tapsell. 2013. Revisiting the River Skerne: the long-term social benefits of river rehabilitation. Landscape 
and Urban Planning 113:94-103. http://dx.doi.org/10.1016/j. landurbplan.2013.01.009

Adger, W. N. 2006. Vulnerability. Global Environmental Change 16:268-281. http://dx.doi.org/10.1016/j.gloenvcha.2006.02.006

Angel, P. N., D. H. Graves, C. Barton, R. C. Warner, P. W. Conrad, R. J. Sweigard, and C. Agouridis. 2006. Surface mine reforestation research: evaluation of tree response to low compaction reclamation techniques. In R. I. Barnhisel, editor. Proceedings of the 7th International Conference on Acid Rock Drainage (ICARD), 26-30 March, St. Louis Missouri, USA. American Society of Mining and Reclamation (ASMR), Lexington, Kentucky, USA.

Aronson, J., and S. Alexander. 2013. Ecosystem restoration is now a global priority: time to roll up our sleeves. Restoration Ecology 21:293-296. http://dx.doi.org/10.1111/rec.12011

Bernhardt, E. S., E. B. Sudduth, M. A. Palmer, J. D. Allan, J. L. Meyer, G. Alexander, J. Follastad-Shah, B. Hassett, R. Jenkinson, R. Lave, J. Rumps, and L. Pagano. 2007. Restoring rivers one reach at a time: results from a survey of U.S. river restoration practitioners. Restoration Ecology 15:482-493. http://dx.doi. org/10.1111/j.1526-100X.2007.00244.X

Bohlen, P., S. Lynch, L. Shabman, M. Clark, S. Shukla, and H. Swain. 2009. Paying for environmental services from agricultural lands: an example from the northern Everglades. Frontiers in Ecology and the Environment 7:46-55. http://dx.doi.org/10.1890/080107

Bonaiuto, M., G. Carrus, H. Martorella, and M. Bonnes. 2002. Local identity processes and environmental attitudes in land use changes: the case of natural protected areas. Journal of Economic Psychology 23(5):631-653. http://dx.doi.org/10.1016/S0167-4870 (02)00121-6

Boschmann, E. E., and E. Cubbon. 2014. Sketch maps and qualitative GIS: using cartographies of individual spatial narratives in geographic research. Professional Geographer 66 (2):236-248. http://dx.doi.org/10.1080/00330124.2013.781490

Buijs, A. E. 2009. Public support for river restoration. A mixedmethod study into local residents' support for and framing of river management and ecological restoration in the Dutch floodplains. Journal of Environmental Management 90:2680-2689. http://dx.doi.org/10.1016/j.jenvman.2009.02.006

Carpenter, S. R., and W. A. Brock. 2008. Adaptive capacity and traps. Ecology and Society 13(2):40. http://dx.doi.org/10.5751/ ES-02716-130240

Carpenter, S. R., C. Folke, A. Norström, O. Olsson, L. Schultz, B. Agarwal, P. Balvanera, B. Campbell, J. C. Castilla, W. Cramer, et al. 2012. Program on ecosystem change and society: an international research strategy for integrated social-ecological systems. Current Opinion in Environmental Sustainability 4:134-138. http://dx.doi.org/10.1016/j.cosust.2012.01.001

Cinner, J. E., C. Huchery, C. C. Hicks, T. M. Daw, N. Marshall, A. Wamukota, and E. H. Allison. 2015. Changes in adaptive capacity of Kenyan fishing communities. Nature Climate Change 5:872-876 http://dx.doi.org/10.1038/nclimate2690

Clewell, A. F., and J. Aronson. 2006. Motivations for the restoration of ecosystems. Conservation Biology 20:420-428. http://dx.doi.org/10.1111/j.1523-1739.2006.00340.x
Cooper, C. B., J. Dickinson, T. Phillips, and R. Bonney. 2007. Citizen science as a tool for conservation in residential ecosystems. Ecology and Society 12(2):11. http://dx.doi.org/10.5751/ ES-02197-120211

Costanza, R., R. d'Arge, R. de Groot, S. Farber, M. Grasso, B. Hannon, K. Limburg, S. Naeem, R. V. O'Neill, J. Paruelo, R. G. Raskin, P. Sutton, and M. van den Belt. 1997. The value of the world's ecosystem services and natural capital. Nature 387:253-260. http://dx.doi.org/10.1038/387253a0

Cutter, S. L., L. Barnes, M. Berry, C. Burton, E. Evans, E. Tate, and J. Webb. 2008. A place-based model for understanding community resilience to natural disasters. Global Environmental Change 18:598-606. http://dx.doi.org/10.1016/j.gloenvcha.2008.07.013

Dallaire, K., J. Skousen, and J. Schuler. 2015. Height of three hardwood species growing on mine sites reclaimed using the forestry reclamation approach compared to natural conditions. Journal of the American Society of Mining and Reclamation 4:20-35. http://dx.doi.org/10.21000/JASMR15020020

Devine-Wright, P. 2009. Rethinking NIMBYism: the role of place attachment and place identity in explaining place-protective action. Journal of Community \& Applied Social Psychology 19 (6):426-441. http://dx.doi.org/10.1002/casp.1004

Doiron, S., and S. Weissenberger. 2014. Sustainable dive tourism: social and environmental impacts - the case of Roatan, Honduras. Tourism Management Perspectives 10:19-26. http://dx.doi. org/10.1016/j.tmp.2013.12.003

Donnelly, M., M. Shaffer, S. Connor, P. Sacks, and L. Walters. 2017. Using mangroves to stabilize coastal historic sites: deployment success versus natural recruitment. Hydrobiologia 803:389-401. http://dx.doi.org/10.1007/s10750-017-3155-x

Eakin, H., and A. L. Luers. 2006. Assessing the vulnerability of social-environmental systems. Annual Review of Environment and Resources 31:365-394. http://dx.doi.org/10.1146/annurev. energy.30.050504.144352

Edelenbos, J., A. Van Buuren, D. Roth, and M. Winnubst. 2017. Stakeholder initiatives in flood risk management: exploring the role and impact of bottom-up initiatives in three 'Room for the River' projects in the Netherlands. Journal of Environmental Planning and Management 60:47-66. http://dx.doi. org/10.1080/09640568.2016.1140025

Elliott, M., D. Burdon, K. L. Hemingway, and S. E. Apitz. 2007. Estuarine, coastal, and marine ecosystem restoration: confusing management and science - a revision of concepts. Estuarine Coastal and Shelf Science 74:349-366. http://dx.doi.org/10.1016/ j.ecss.2007.05.034

Elston, D. E. 2009. Characterizing community impacts of small dam removal: a case study of the Brownsville Dam. Thesis. Oregon State University, Corvallis, Oregon, USA. [online] URL: http:// ir.library.oregonstate.edu/concern/graduate thesis or dissertations/ $\underline{\mathrm{kh} 04 \mathrm{dr} 78 \mathrm{p}}$

Engle, N. L. 2011. Adaptive capacity and its assessment. Global Environmental Change 21:647-656. http://dx.doi.org/10.1016/j. gloenvcha.2011.01.019

Farber, S., R. Costanza, D. L. Childers, J. Erickson, K. Gross, M. Grove, C. S. Hokinson, J. Kahn, S. Pincetl, A. Troy, P. Warren, 
and M. Wilson. 2006. Linking ecology and economics for ecosystem management. BioScience 56:121-133. http://dx.doi. org/10.1641/0006-3568(2006)056[0121:LEAEFE]2.0.CO;2

Florida Department of Environmental Protection (FDEP). 1995. A socio-economic study of the Rodman Reservoir, Vol. 1. Florida Department of Environmental Protection, Economic Analysis Section, Tallahassee, Florida, USA.

Folke, C. 2006. Resilience: the emergence of a perspective for social-ecological systems analyses. Global Environmental Change 16:253-267. http://dx.doi.org/10.1016/j.gloenvcha.2006.04.002

Folke, C., S. R. Carpenter, B. Walker, M. Scheffer, T. Chapin, and J. Rockström. 2010. Resilience thinking: integrating resilience, adaptability and transformability. Ecology and Society 15(4):20. http://dx.doi.org/10.5751/ES-03610-150420

France, R. L. 2016. From land to sea: governance-management lessons from terrestrial restoration research useful for developing and expanding social-ecological marine restoration. Ocean and Coastal Management 133:64-71. http://dx.doi.org/10.1016/j. ocecoaman.2016.08.022

Gallopin, G. C. 2006. Linkages between vulnerability, resilience, and adaptive capacity. Global Environmental Change 16:293-303. http://dx.doi.org/10.1016/j.gloenvcha.2006.02.004

Geist, C., and S. M. Galatowitsch. 1999. Reciprocal model for meeting ecological and human needs in restoration projects. Conservation Biology 13:970-979. http://dx.doi.org/10.1046/ j.1523-1739.1999.98074.x

Higgs, E. 2012. Human dimensions of ecological restoration: integrating science, nature, and culture. Island, Washington, D.C., USA.

Holl, K. D. 2002. Long-term vegetation recovery on reclaimed coal surface mines in the eastern USA. Journal of Applied Ecology 39:960-970. http://dx.doi.org/10.1046/j.1365-2664.2002.00767.x

Holl, K. D., and R. B. Howarth. 2000. Paying for restoration. Restoration Ecology 8:260-267. http://dx.doi.org/10.1046/ j.1526-100x.2000.80037.x

Indian River Lagoon National Estuary Program (IRL NEP). 2008. Indian River Lagoon Comprehensive Conservation Management Plan Update. Indian River Lagoon National Estuary Program. Palm Bay, Florida, USA.

Jones, A. T., J. M. Galbraith, and J. A. Burger. 2005. Development of a forest site quality classification model for mine soils in the Appalachian Coalfield Region. Pages 523-540 in National Meeting American Society for Mining and Reclamation Lexington, Kentucky, USA.

Jorgensen, B. S., and R. C. Stedman. 2001. Sense of place as an attitude: Lakeshore owner's attitudes toward their properties. Journal of Environmental Psychology 21:233-248. http://dx.doi. org/10.1006/jevp.2001.0226

Kendy, E., K. W. Flessa, K. J. Schlatter, C. A. de la Parra, O. M. H. Huerta, Y. K. Carrillo-Guerrero, and E. Guillen. 2017. Leveraging environmental flows to reform water management policy: lessons learned from the 2014 Colorado River Delta pulse flow. Ecological Engineering 106:683-694. http://dx.doi. org/10.1016/j.ecoleng.2017.02.012
Kittinger, J. N., T. M. Bambico, D. Minton, A. Miller, M. Mejia, N. Kalei, B. Wong, and E. W. Glazier. 2016. Restoring ecosystems, restoring community: socioeconomic and cultural dimensions of a community-based coral reef restoration project. Regional Environmental Change 16(2):301-313. http://dx.doi.org/10.1007/ s10113-013-0572-X

Kondolf, G. M., and E. R. Micheli. 1995. Evaluating stream restoration projects. Environmental Management 19:1-15. http:// dx.doi.org/10.1007/BF02471999

Lee, M., and P. Hancock. 2011. Restoration and stewardship volunteerism. Pages 23-38 in D. Egan, E. E. Hjerpe, and J. Abrams, editors. Human dimensions of ecological restoration: integrating science, nature, and culture. Island, Washington, D.C., USA. http://dx.doi.org/10.5822/978-1-61091-039-2 2

Lewis, R. R. 2012. Management and restoration of the fish populations of Silver Springs and the Middle and Lower Ocklawaha River, Florida, USA. Putnam County Environmental Council, Interlachen, Florida, USA.

Liu, J., T. Dietz, S. R. Carpenter, M. Alberti, C. Folke, E. Moran, A. N. Pell, P. Deadman, T. Kratz, J. Lubchenco, et al. 2007. Complexity of coupled human and natural systems. Science 317:1513-1516. http://dx.doi.org/10.1126/science.1144004

Lubchenco, J., A. K. Barner, E. B. Cerny-Chipman, and J. N. Reimer. 2015. Sustainability rooted in science. Nature Geoscience 8:741-745. http://dx.doi.org/10.1038/ngeo2552

Luers, A. L., D. B. Lobell, L. S. Sklar, C. L. Addams, and P. A. Matson. 2003. A method for quantifying vulnerability, applied to the agricultural system of the Yaqui Valley, Mexico. Global Environmental Change 13:255-267. http://dx.doi.org/10.1016/ S0959-3780(03)00054-2

Massey, D. 1993. Power-geometry and a progressive sense of place. Chapter 4 in J. Bird, B. Curtis, T. Putnam, G. Robertson, and L. Tickner, editors. Mapping the futures: local cultures, global change. Routledge, London, UK.

Masterson, V. A., R. C. Stedman, J. Enqvist, M. Tengö, M. Giusti, D. Wahl, and U. Svedin. 2017. The contribution of sense of place to social-ecological systems research: a review and research agenda. Ecology and Society 22(1):49. http://dx.doi.org/10.5751/ ES-08872-220149

Marttila, M., K. Kyllönen, and T. P. Karjalainen. 2016. Social success of in-stream habitat improvement: from fisheries enhancement to the delivery of multiple ecosystem services. Ecology and Society 21(1):4. http://dx.doi.org/10.5751/ES-08118-210104

Millennium Ecosystem Assessment. 2005. Ecosystems and human well-being: synthesis. Island, Washington, D.C., USA.

Molles, M. C., C. S. Crawford, L. M. Ellis, H. M. Valett, and C. N. Dahm. 1998. Managed flooding for riparian ecosystem restoration. Bioscience 48:749-756. http://dx.doi.org/10.2307/1313337

Mooney, H., A. Larigauderie, M. Cesario, T. Elmquist, O. HoeghGuldberg, S. Lavorel, G. M. Mace, M. Palmer, R. Scholes and T. Yahara. 2009. Biodiversity, climate change, and ecosystem services. Current Opinion in Environmental Sustainability 1:46-54. http://dx.doi.org/10.1016/j.cosust.2009.07.006 
Mumby, P. J., I. Chollett, Y.-M. Bozec, and N. H Wolff. 2014. Ecological resilience, robustness and vulnerability: how do these concepts benefit ecosystem management? Current Opinion in Environmental Sustainability 7:22-27. http://dx.doi.org/10.1016/j. cosust.2013.11.021

Nelson, S. M., J. Ramírez-Hernández, J. E. Rodríguez-Burgueño, J. Milliken, J. R. Kennedy, F. Zamora-Arroyo, K. Schlatter, E. Santiago-Serrano, and E. Carrera-Villa. 2017. A history of the 2014 Minute 319 environmental pulse flow as documented by field measurements and satellite imagery. Ecological Engineering 106:733-748. http://dx.doi.org/10.1016/j.ecoleng.2016.10.040

Noll, S., and D. Tegeder. 2009. Ditch of dreams: the cross Florida barge canal and the struggle for Florida's future. University Press of Florida, Gainesville, Florida, USA.

Ogden, J. C., S. M. Davis, K. J. Jacobs, T. Barnes, and H. E. Fling. 2005. The use of conceptual ecological models to guide ecosystem restoration in south Florida. Wetlands 25:795-809. http://dx.doi. org/10.1672/0277-5212(2005)025[0795:TUOCEM]2.0.CO;2

Oregon Department of Fish and Wildlife (ODFW). 2007. Rouge Spring Chinook salmon conservation plan. Oregon Department of Fish and Wildlife, Salem, Oregon, USA. [online] URL: http:// www.dfw.state.or.us/fish/CRP/docs/rogue_spring_chinook/ final rogue CHS plan.pdf

Ostrom, E. 2009. A general framework for analyzing sustainability of social-ecological systems. Science 325:419-422. http://dx.doi.org/10.1126/science.1172133

Palmer, M. A., E. S. Bernhardt, J. D. Allan, P. S. Lake, G. Alexander, S. Brooks, J. Carr, S. Clayton, C. N. Dahm, J. Follstad Shah, et al. 2005. Standards for ecologically successful river restoration. Journal of Applied Ecology 42:208-217. http://dx.doi. org/10.1111/j.1365-2664.2005.01004.X

Palmer, M. A., and J. B. Ruhl. 2015. Aligning restoration science and the law to sustain ecological infrastructure for the future. Frontiers in Ecology and the Environment 13:512-519. http://dx. doi.org/10.1890/150053

Reed, M. S. 2008. Stakeholder participation for environmental management: a literature review. Biological Conservation 141:2417-2431. http://dx.doi.org/10.1016/j.biocon.2008.07.014

Relph, E. 1976. Place and placelessness. Vol. 67. Pion, London, UK.

Rey, J. R., D. B. Carlson, and R. E. Brockmeyer. 2012. Coastal wetland management in Florida: environmental concerns and human health. Wetlands Ecology and Management 20:197-211. http://dx.doi.org/10.1007/s11273-011-9235-1

Rivera, F. I., and N. Kapucu. 2015. Disaster vulnerability, hazards and resilience. Springer, New York, New York, USA. http://dx. doi.org/10.1007/978-3-319-16453-3

Robards, M. D., M. L. Schoon, C. L. Meek, and N. L. Engle. 2011. The importance of social drivers in the resilient provision of ecosystem services. Global Environmental Change 21:522-529. http://dx.doi.org/10.1016/j.gloenvcha.2010.12.004

Robinson, J. 2009. Savage Rapids lesson: removing dams no easy task. Oregon Public Broadcasting, 23 June. [online] URL: http:// www.opb.org/news/article/savage-rapids-lesson-removing-dams-noeasy-task/

Rogers, M. W., M. S. Allen, and M. D. Jones. 2005. Relationship between river surface level and fish assemblage in the Ocklawaha River, Florida. River Research and Applications 21:501-511. http:// dx.doi.org/10.1002/rra.818

Rose, G. 1995. Place and identity: a sense of place. Pages 87-132 in D. Massey and P. Jess, editors. A place in the world?: places, cultures and globalization. Oxford University Press, Oxford, UK.

Ruiz-Jaen, M. C., and T. M. Aide. 2005. Restoration success: How is it being measured? Restoration Ecology 13:569-577. http://dx. doi.org/10.1111/j.1526-100X.2005.00072.X

Satz, D., R. K. Gould, K. M. A. Chan, A. Guerry, B. Norton, T. Satterfield, B. S. Halpern, J. Levine, U. Woodside, N. Hannahs, X. Basurto, and S. Klain. 2013. The challenges of incorporating cultural ecosystem services into environmental assessment. Ambio 42(6):675-684. http://dx.doi.org/10.1007/s13280-013-0386-6

Scannel, L., and R. Gifford. 2010. Defining place attachment: a tripartite organizing framework. Journal of Environmental Psychology 30:1-10. http://dx.doi.org/10.1016/j.jenvp.2009.09.006

Schroter, D., C. Polsky, and A. G. Pratt. 2005. Assessing vulnerabilities to the effects of global change: an eight step approach. Mitigation and Adaptation Strategies for Global Change 10:573-596. http://dx.doi.org/10.1007/s11027-005-6135-9

Shamai, S. 1991. Sense of place: an empirical measurement. Geoforum 22:347-358. http://dx.doi.org/10.1016/0016-7185(91) 90017-K

Shamai, S., and Z. Ilatov. 2005. Measuring sense of place: methodological aspects. Tijdschrift voor Economische en Sociale Geografie 96:467-476. http://dx.doi.org/10.1111/j.1467-9663.2005.00479. $\underline{x}$

Small, N., M. Munday, and I. Durance. 2017. The challenge of valuing ecosystem services that have no material benefits. Global Environmental Change 44:57-67. http://dx.doi.org/10.1016/j. gloenvcha.2017.03.005

Spies, T. A., E. M. White, J. D. Kline, A. P. Fischer, A. Ager, J. Bailey, J. Bolte, J. Koch, E. Platt, C. S. Olsen, D. Jacobs, B. Shindler, M. M. Steen-Adams, and R. Hammer. 2014. Examining fire-prone forest landscapes as coupled human and natural systems. Ecology and Society 19(3):9. http://dx.doi.org/10.5751/ ES-06584-190309

Stanturf, J. A., S. H. Schoenholtz, C. J. Schweitzer, and J. P. Shepard. 2001. Achieving restoration success: myths in bottomland hardwood forests. Restoration Ecology 9:189-200. http://dx.doi.org/10.1046/j.1526-100x.2001.009002189.x

Stedman, R. C. 2003. Sense of place and forest science: toward a program of quantitative research. Forest Science 49(6):822-829.

Tuan, Y. F. 1977. Space and place: the perspective of experience. University of Minnesota Press, Minneapolis, Minnesota, USA.

Tullos, D. D., D. S. Finn, and C. Walter. 2014. Geomorphic and ecological disturbance and recovery from two small dams and their removal. PLoS ONE 9(9):e108091. http://dx.doi. org/10.1371/journal.pone.0108091 
Turner, B. L., R. E. Kasperson, P. A. Matson, J. J. McCarthy, R. W. Corell, L. Christensen, N. Eckley, J. X. Kasperson, A. Luers, M. L. Martello, C. Polsky, A. Pulsipher, and A. Schiller. 2003. A framework for vulnerability analysis in sustainability science. Proceedings of the National Academy of Sciences of the United States of America 100:8074-8079. http://dx.doi.org/10.1073/ pnas. 1231335100

United Nations General Assembly. 2015. Transforming our world: the 2030 agenda for sustainable development. Annex A/69/L.85. United Nations, New York, New York, USA. [online] URL: http://go.nature.com/qcryu 5

Valentine, G. 2007. Theorizing and researching intersectionality: a challenge for feminist geography. Professional Geographer 59:10-21. http://dx.doi.org/10.1111/j.1467-9272.2007.00587.x

Walker, B., C. S. Holling, S. R. Carpenter, and A. Kinzig. 2004. Resilience, adaptability and transformability in social-ecological systems. Ecology and Society 9(2):5. http://dx.doi.org/10.5751/ ES-00650-090205

Walters, L., M. Donnelly, P. Sacks, and D. Campbell. 2017. Lessons learned from living shoreline stabilization in popular tourist areas: boat wakes, volunteer support and protecting historic structures. Chapter 12 in D. M. Bilkovic, M. M. Mitchell, M. K. La Peyre, and J. D. Toft, editors. Living shorelines: the science and management of nature-based coastal protection. CRC, Boca Raton, Florida, USA.

Westling, E. L., B. W. J. Surridge, L. Sharp, and D. N. Lerner. 2014. Making sense of landscape change: long-term perceptions among local residents following river restoration. Journal of Hydrology 519:2613-2623. http://dx.doi.org/10.1016/j.jhydrol.2014.09.029

Wortley, L., J.-M. Hero, and M. Howes. 2013. Evaluating ecological restoration success: a review of the literature. Restoration Ecology 21:537-543. http://dx.doi.org/10.1111/ rec. 12028 